\title{
The Historical Changes of Rural Education Development since the Founding of the PRC
}

\author{
Ji Jun \\ School of Marxism,Tianjin University Of Commerce,Tianjin, 300134, China \\ jijun@163.com
}

Key words: New China; The rural education; Basic education; Management system; Administrative management; Systematic reform

\begin{abstract}
Since the founding of new China in more than 70 years, for its foundational status and the fact that it is the "undertaker of social reform era", basic rural education plays a key role in promoting the new rural construction and cultivating the high-quality talents in rural area. In this article, the author tries from the macroscopic angle to systematically found change course of rural basic education management system since the founding of the PRC. Besides, the author conducts longitudinal analysis of the formation background, the change process, stage characteristics and reform difficulties in each stage that drive the formation of basic rural education system. The author deeply analyzes the relationship among basic rural education in our country's countryside, systematic reformation and changes in economic system, as well as other major factors influencing the reform. And based on the above, the author summarizes the experiences of the reform.
\end{abstract}

\section{Introduction}

Based on historical review of the reform of rural basic education management system of our country, we can see that since the founding of new China, most of the researches that based on the reform of rural basic education management system of our country are made in the 30 years after the reform and open policy is carried out. Namely, the current rural basic education management system in China and the decentralized management system under the unified leadership of the central government are tinged with the features of proper combination of central and local management that based on the centralization of authority. Before the reform and open policy, researches of rural basic education management system are very few. For the research content, it is mainly about the problems of policy analysis of the reform, experience reports of the local reformation and education fairness in the present dual structure between urban and rural areas. The researches of this period-30 years before the founding of RPC are summarized as time events based on the central education department organizational events taking the rules and regulations as base. Therefore, those researches lack the elements, hierarchy and mutual relationship that are specifically made for rural education management. Besides, the researches lack historical and systematic theoretical research.

Based on the current to roughly review the three stages of systematic reformation of China's basic education management system reformation in rural area since the founding of our country: setting up the new "centralized and unified" system (1949 1949), adjustment and strengthening of the system under the unified leadership of the “decentralization” (1977 1977), comprehensive advancement of the education system that is "mainly based on county" (2001 - present). 


\section{The Establishment of “Unified Leadership and Decentralized Administration” (1949-1977)}

\section{The Establishment of a New “Centralized and Unified” System（1949-1955）.}

(1) To put the rural education career into unified leadership. New China's education should be based on the education experience of old liberated areas, and draw lessons from the advanced education construction achievements of the Soviet Union, and at the same time absorb some useful experience of the old education. At the same time, we should put forward the organization and leadership principle of education, and the implementation of the education of workers and peasants should be firstly used to train cadres of workers and peasants and activists. And we should adjust measures to local conditions and given priority to implementing culture, policy and current affairs education. This meeting has guiding significance for the construction of the new China's education cause.

(2) Divide the rural education administrative liabilities

With the development of the national construction, the national basic education has rapidly developed. And the above measure standardized the rural basic education system, made clear their duties of management, and made the rural basic education gradually step toward formalization. People's education business has made certain achievements and progress after "recovery, reform, consolidation and development". Or we can say that according to the extreme poverty and backwardness in that period, it is good for us to use that kind of way to recover and develop rural education. Macroeconomic regulation and planned control party of the government is the effective guarantee of the development of education cause.

(3) Establishing vertical management structure of rural education system

Education administrative institutions of new China, an administration authority, where the new Chinese central government and local governments at various levels could exercise the education administrative functions, are organic parts of the governments at all levels. Its status will change with the changes in the national political, economic, cultural system reform, the key points of the national education cause and the scope and functions of governmental function.

From 1949 to 1954, the organization relationship in education management gradually becomes clear. The education leadership and management authority of this period are concentrated respectively in the central, provincial/municipal and county governments and education administrative departments, which reflects the preliminary establishment of the "new China's socialist education system” with highly centralized and unified characteristic.

\section{Analysis of the Historical Experience of Rural Basic Education Management System Changes}

Define the Duties--Systematic Choice of Centralization and Decentralization. Sound education management system is an absolute guarantee to promote the development of one-hundred-national education cause. Centralization and decentralization, however, as the main contradiction in the administrative system reform are always there. And the two are related to every step in the reformation, so a balanced development between the two is the key factor influencing the concrete implementation process of education management system.

\section{Specification Division--Optimizing the Organization Structure to Reduce Hierarchies.}

1. The policy guidance of rural education's fair decisions. Breaking the highly centralization and optimizing the power structure are the first demand of basic education management system reform in our country. And they are also the needs for the nation to adapt new level management. To solve the problem of fairness in education, we must first start from the education policy to search methods. "Fairness" is the intrinsic attribute and the primary value of education policy. Unfair education 
happens due to the fact that the education policy makers, on the aspect of guiding policy, despise even ignore the policy attribute of fair education, which makes the unfairness in education emerges.

2. Matrix design of optimizing the organizational structure. An education ministry is responsible for uncountable departments of the country's innumerable institutions. Only the departments and the industries in charge of vocational education management in Chongqing are as many as 22. When there is a conflict, the people in the management organization departments would emphasize the objective factors or take a perfunctory excuse. At the same time, there lacks authoritative joint conference and coordination agencies. Besides, the education administrative departments and related departments are at the same level, so it is difficult for people to request, and thus unable to understand the progress. And the check can't be implemented. Thus on the surface, the government carried out joint management, in fact, it can't deal with all these at the same time.

Law Enforcement and Supervision--Establish and Improve the Legal Protection System. Ancient Chinese Confucianism holds that: in the rule by man and the rule of law, and legal system, the theory of the sage governance is the starting point of the rule of law, the foolish idea in the human over law concept holding "administration by the people" and "when a man dies his administration will be cast away” place the ruler over the law. China's feudal ruling ideas have been rooted in Chinese feudal society for thousands of years. However, the differentiation in classes and stratums does not make people, especially the people in the rural areas awaken after the land reform movement eliminated class differentiation, and their legal consciousness is still indifference.

Increasing Investment--Promote the Financial Management in Rural Areas. Strengthen multi-channel investment in the education of rural areas. "Adjust measures to local conditions" to rebuild the system of transferring payments. Taking "urban and rural areas as a whole" to improve the financial system in the education in rural areas.

Autonomous Management--the Administrative Organ Transform Government Functions. Chinese Education Reform and Development Compendium (hereinafter referred to as the Outline) points out that the change of government functions to necessary administrative means and the legislation, funding, planning, information services and policy guidance. In this way, the government conducts "macroscopic management" in the management of education cause. Focus our work on specific work that guided by the macroscopic planning and policy including administration based on law, social development, economic construction, education resources allocation. Clearly divide the administrative departments according to their relationship, which is to say the government departments should conduct indirect management. The government departments should overcome the mandatory plans adopted for a long time. Besides, it should take the resolutions, decisions, orders, directives and other administrative measures in administrative management organs to conduct comprehensive treatment.

\section{Conclusion}

The status of rural basic education in the education system could be called as the base of the "foundation". In China, rural basic education is with the particular label-rural in the wide geographical environment. So for the effective management of the rural basic education, we should promote the new rural construction to strengthen the reserve and ascending of rural human resources, and effectively protect the general improvement of people's overall quality at the same time. At the same time, because the rural basic education deeply influences China's overall education, besides, it is the key to eradicate illiteracy and develop rural construction, thus the central and local governments at all levels attaches great importance to the rural basic education in more than 60 years since the founding of new China.

In management alterations of new China's rural basic education, the Chinese government 
established education management system with Chinese characteristics in rural basic education in the political and economic systematic aspects. In rural social development process, from the township thought in the period that China was founded to today's self-governance among villagers, the construction and development of China's grassroots regime were hard all the way, even if there were many obstacles in the process of developing, out country also firmly has been walking on the way to build a new socialist countryside. The reform of central and local administrative functions not only led to the development and progress of rural economy, but also drove the reform and development of the management system of education. Driven by political factors and economic factors, under the influence of policy guidance, construction of legal system, supervision mechanism and the synergy of education systems, China has achieved the nine-year compulsory education task before the new century eve. Besides, China has made the western crucial strategic planning.

Everything has double edges, yet "reform" is the combination of two synonymous words. When we are faced with marvelous chapter, we also should keep in mind and remember this chapter deeply. In the evolution of history, we should keep a clear understanding, while take the history as reference look inside ourselves at the same time. In the process of development, we should keep ourselves down-to-earth, and adjust measures to local conditions, besides, we must not blindly take the much the better as a principle and equal the big number to good quality. In the process of reform, we should deeply analyze the disadvantages and advantages, and shouldn't perfunctory, prevarication and delay our tasks in chaos. In practical situation, we should conduct research in a scientific way, think carefully, take the law as standard, and take the facts as references. In the forwarding process, we should be bold, yet should not lose one thing while attending the other.

\section{References}

[1] Tao Xiping. Dictionary of Education Evaluation [M]. Beijing: Beijing Normal University Press, 1998.432.

[2] Zhang Huanting. Education Dictionary [M] Nanjing: Jiangsu Education Press. 1989.758.

[3]Qin Zhihua, Li Kexin and Chen Xiankui. China's Rural Work Big Dictionary [M]. Beijing: The Police Officer Education Press. 1993.720. 